\title{
Effect of the graded levels of potassium with recommended NP on soil properties under maize cultivation in alfisols of Mandya, Karnataka
}

\section{K. SRINIVASA, G. S. YOGESH, B. R. JAGADEESH AND T. CHIKKARAMAPPA}

Received : 10.03.2017; Revised : 21.04.2017; Accepted : 03.05.2017

\section{MEMBERS OF RESEARCH FORUM}

Corresponding author : D.K. SRINIVASA, Department of Soil Science and Agricultural Chemistry, University of Agricultural Sciences, GKVK, BENGALURU (KARNATAKA) INDIA

\section{Co-authors :}

G. S. YOGESH, Krishi Vigyan Kendra (U.A.S.), Chamaraja Nagar, BENGALURU (KARNATAKA) INDIA

B.R. JAGADEESH, College of Agriculture (U.A.S.)

HANUMANAMATTI (KARNATAKA) INDIA

\section{T. CHIKKARAMAPPA,}

Department of Soil Science and Agricultural Chemistry, University of Agricultural Sciences, GKVK, BENGALURU (KARNATAKA) INDIA

\section{Summary}

During Kharif 2012, a field experiment was conducted in an alfisol of Mandya with different levels of potassium under irrigated maize to know the impact of application of potassium on various soil properties. The study involved nine treatments viz., Recommended NPK as per UAS (B) package, rec. NPK 15 DAS, NP + 75, 100, 125 per cent rec. K in splits, NP only and absolute control, replicated thrice and the statistical design was RCBD. The results of the experiment indicated that, soil $\mathrm{pH}$ and EC not varied much due to application of graded levels of potassium in maize. Highest organic carbon content was recorded in the treatment of recommended dose of NP + recommended dose of K in two splits (basal and at the time of topdressing). The soil available NPK content after the harvest of maize crop differed due to application of graded levels of potassium and the highest NPK content was recoded with the application of recommended NPK as per UAS (B) package and lowest available nitrogen was registered in the control. Similar trend was also observed with respect to exchangeable $\mathrm{Ca}$, $\mathrm{Mg}$ and available sulphur. Application of recommended NP + 125 per cent of recommended K in two splits recorded the higher values for the various soil properties studied.

Key words : Maize, Graded levels of potassium, Soil properties

How to cite this article : Srinivasa, D. K., Yogesh, G. S., Jagadeesh, B.R. and Chikkaramappa, T. (2017). Effect of the graded levels of potassium with recommended NP on soil properties under maize cultivation in alfisols of Mandya. Asian J. Soil Sci., 12 (1) : 98-102 : DOI : 10.15740/HAS/AJSS/12.1/ 98-102. 